\title{
"Apart but Together": Isolation, Connections and Affection Among the Members of Afro-Brazilian Religions During the Covid-19 Pandemic
}

\author{
Daniela Calvo ${ }^{1,2}$
}

Received: 16 January 2021 / Accepted: 11 April 2021/ Published online: 4 May 2021

(C) The Author(s), under exclusive licence to Springer Nature Switzerland AG 2021

\begin{abstract}
What does social isolation mean for members of religious groups who constitute themselves as a family and who value meetings, physical contact and bodily experience? What strategies do they follow to face the loneliness that isolation entails? Since the middle of March 2020, when the World Health Organization (WHO) declared the risk of pandemic and the number of contagions of SARS-Cov-2 in Brazil was beginning to grow, most communities of Afro-Brazilian religions have adhered to social isolation in order to avoid contagion, protect their members and contribute to containing the progress of the pandemic among the population. The phrase "Apart but together", which accompanies the shared intention of preserving life and the suspension of religious celebrations and meetings, is manifested in an intensification of virtual communications, in seminars, debates, prayers and rituals with online participation. Messages, posts, photos and videos reconstitute a network of relationships, care, affection and solidarity and reaffirm belongings and identities.
\end{abstract}

Keywords Covid-19 · Pandemic · Afro-Brazilian religions · Isolation · Social networks

\section{Introduction}

The Covid-19 pandemic quickly became a global emergency. When the World Health Organization (WHO) recommended following certain restrictions and behaviours in order to contain the spread of the new coronavirus, measures such as lockdown, quarantine, "social isolation" and "social distancing" began to be carried out, to a greater or lesser extent, in different countries. The impossibility of detecting

Daniela Calvo

dnlclv7@gmail.com

1 Universidade do Estado do Rio de Janeiro, Rio de Janeiro, Brazil

2 Montiglio Monferrato, Italy 
asymptomatic people without massive testing made anyone a possible vehicle of contagion, and preventive measures were recommended to everyone in order to not be infected nor to infect others.

In Brazil, the response to the pandemic has been compromised by structural problems and the overlap of different positions among government agencies, so the sanitary emergency was accompanied by social, political, economic and information crises. President Jair Bolsonaro, adopting a denialist position, stood against social isolation and, under the pressure of Christian churches, declared religious office an essential service, so that churches could continue their activities. ${ }^{1}$

The members of Afro-Brazilian religions-in contrast with Christian churches (especially evangelical sectors) aligned with the government, that kept their temples open and maintained their religious offices during pandemichave recommended social isolation as the main measure to prevent contagion, protect the most vulnerable people and contribute to the containment of the pandemic in the country (Fig. 1).

Behaviour protocols were created on the basis of practices and cosmology in the terreiros, ${ }^{2}$ advising adoption of the following measures: suspend the liturgical calendar and cease any activity open to the public; reschedule public feasts; avoid kissing the hand for blessings; avoid, if possible, initiations, and if otherwise, carry out the rituals in the presence of the smallest possible number of people; prohibit visits to people, especially to foreign tourists; undertake therapeutic rituals and oracular consultations only in urgent cases and with every care for hygiene, in addition to social distancing; avoid crowds in funeral rituals (the coffin must be closed and burial must occur in the ground); suspend social activities, such as courses, lectures and meetings; and protect the elders. ${ }^{3}$

The reaction of members of the different religious communities - as is clear from the comments to these posts, the messages published in their social networks and the reports of my interlocutors - was widespread adherence. Most terreiros continue, as of today, to suspend public events; others celebrated some feasts during the period when the number of contagions for SARS-Cov-2 diminished in their area and closed their doors again when this number increased. Some feasts for órị̀à or spirits of Umbanda, saídas de iyàwó (the celebration that closes the initiation and welcomes new members to the religious community) and other public celebrations were harshly criticized in social media, with comments that reaffirmed the risks of gatherings and the importance of social isolation.

Prolonged isolation (without knowing when the pandemic will end), the health emergency, the fear of contagion and of losing family and friends, the uncertainties and precariousness of different aspects of life (such as work and the economic situation) were not always easy. But new ways to create closeness and to exchange support and affection have arisen.

\footnotetext{
${ }^{1}$ See, for instance, Bandeira and Carranza (2020).

${ }^{2}$ Shrines of Afro-Brazilian religions.

${ }^{3}$ Correio 11 Apr 2020.
} 
What does social isolation mean for members of religious groups who constitute themselves as a family ${ }^{4}$ and value meetings, physical contact and bodily experience? What strategies do they follow to face the loneliness that isolation entails?

Social networks and webinar programs (mainly Facebook, WhatsApp, Instagram, Zoom, Google Meet and YouTube) are the main means of communication for members of Afro-Brazilian religions during the pandemic and were my main research tool. I consulted the content of Facebook and Instagram pages of different terreiros (mainly located in Salvador, Rio de Janeiro and São Paulo) and associations of terreiros (such as RENAFRO Saúde, National Network of Afro-Brazilian Religions and Health, IDAFRO, Institute of Defence of the Rights of Afro-Brazilian Religions, and AFROBRAS, Federation of Afro-Brazilian Religions), Facebook groups that gather members of Afro-Brazilian religions from the whole Brazil and the WhatsApp groups of Candomble terreiros in Rio de Janeiro I participate in, in addition to conducting interviews with my interlocutors and to analyzing the personal conversations I continue to maintain with my friends of Afro-Brazilian religions from Rio de Janeiro, Salvador, Porto Alegre and São Paulo.

I observe that socioeconomic inequalities among the members of Afro-Brazilian religions, and the general population, lead to different access to technology, so that people who do not use the internet and social networks are excluded from virtual connections that could ease isolation; thus, many voices and experiences remain silent or have a much more limited reach.

\section{Waiting for Covid-19 to Pass and Having the Force of the igbin ${ }^{5}$}

Associations of Afro-Brazilian religions, such as RENAFRO Saúde ${ }^{6}$ and AFROBRAS $^{7}$, anticipating the measures adopted by the governments of some states and municipalities, requested, through their Facebook pages, shortly after the WHO declaration of the pandemic risk, social isolation and the suspension of all religious ceremonies and meetings.

Several leaders of Afro-Brazilian religions announced the cancellation of their activities and recommended social isolation to their members and the general population. Comments to these posts show broad support and share the importance of joining in this purpose in order for people to protect themselves and their families and communities.

\footnotetext{
${ }^{4}$ The community of terreiro is defined as familia de santo (family of the saint), and the relations among its members are denoted by a kinship terminology: bàbálórìsà/pai de santo (father of the saint, the main priest of a terreiro, if male), ìyálórișàlmãe de santo (mother of the saint, the main priest, if woman), ìyá/bàbá kékére (mãe/pai pequena/o, little father/mother, the second in the hierarchy of the terreiro), irmão/a de santo (brother/sister of the saint), egbomin (my elder brother/sister), filho/a de santo (son/daughter of the saint). The members of a family of the saint establish, among them, relations marked by solidarity, material and moral assistance and care (sometimes also conflict), substituting, incorporating, expanding or sustaining blood relations. On the relation between family of the saint and of blood, see, for instance, Costa Lima (1977); Souza and Olavo (2020); on the relations among candomblé members see, for instance, Rabelo (2014) and Calvo (2019).

${ }^{5}$ Snail, used in different rituals and offerings. It is the favourite food of Oșálá.

${ }^{6}$ Renafro Saúde. Facebook page.

${ }^{7}$ Afrobras - Federação das Religiões Afro-Brasileiras (2020). Facebook page.
} 


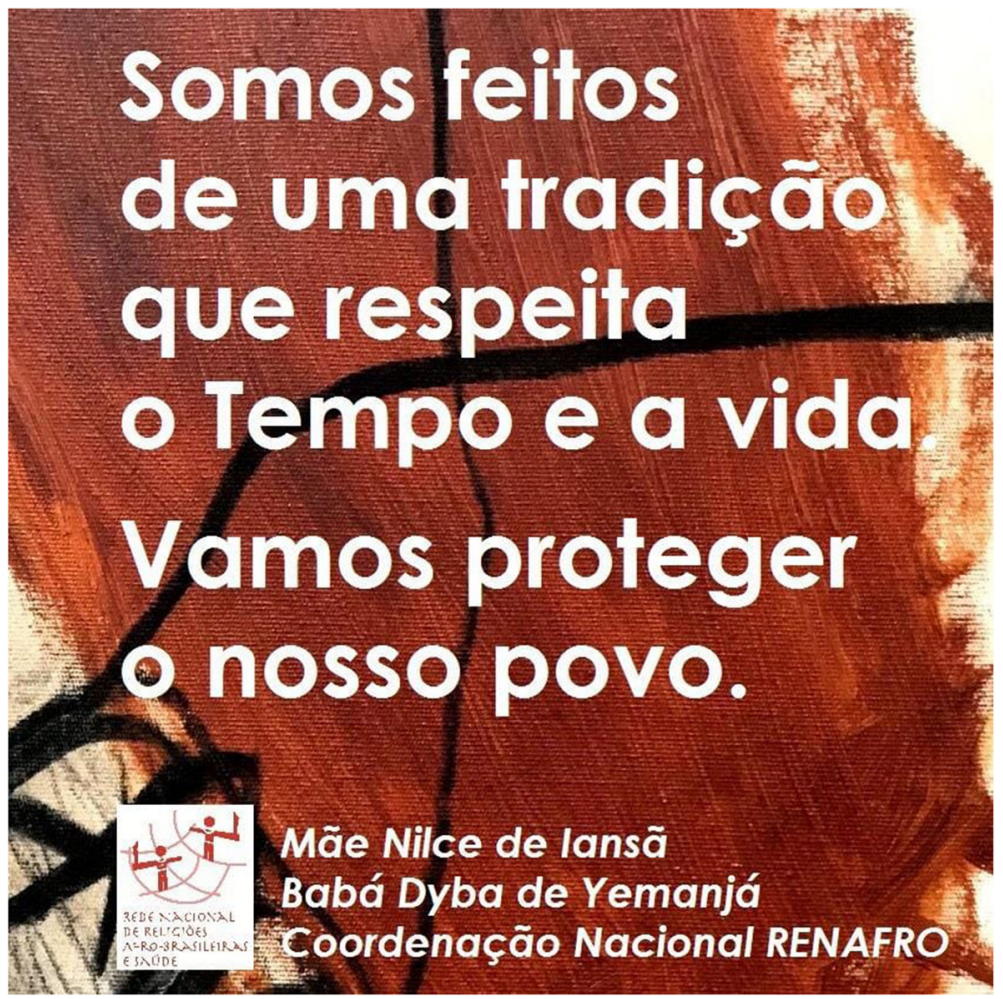

Fig. 1 Post of RENAFRO Saúde recommending protection from Covid-19. Source: RENAFRO Saúde Facebook page

Posts such as "Don't let the virus circulate", "Protect the ones you love", "\#Stayathome", "Apart but together" and "Against the coronavirus, united we are stronger" flooded social networks, with the intention of reaching as many people as possible.

In many posts and in all of my interviews, the importance of respecting isolation as an act of love and as a form of social responsibility of protecting oneself in order to protect others was underscored. For instance, Bábà Mòlá, bàbálórișà of the Candomblé terreiro Ìlé Òbá tì Ṣàngó, located in Vilar dos Teles (Rio de Janeiro) affirmed:

I am very isolated because I think it is a social responsibility, to ourselves and to those we love. So, I suspended any and all kinds of liturgical events in the house, and the consultations. I've remained socially isolated, so I can preserve myself and all those I love. This is a form of social responsibility (Bàbá Mòlá, personal communication).

İyá Glicia of Iyansã, ìyálórìsà of the Candomblé terreiro Ilê Ayaba Afefé-Afeiyka (from the lineage of the Axé Baixão of Salvador), in Rio de Janeiro, is living in social isolation in an integral way, receiving no visits. She stated that: 
The moment is difficult, it is a time for recycling, to review moral values and patterns, social and behavioural values and patterns. So, we're trying to stay alive, healthy, and stay fully healthy. Social isolation is necessary and Afro-Brazilian religions establish the care for each other. Therefore, we are doing so. It is time to stay at home, but it is also time to look inside ourselves and see all this need for brotherhood and companionship (İyá Glicia, personal communication).

The recommendation to stay at home continued to be shared and reinforced when state and municipal governments began to allow the reopening of shops and other activities. A newspaper article in the journal Extra from June 22nd 2020, showing crowded beaches and recreational areas and arguing that the relaxation of isolation was concomitant with an increase in the number of reported cases of Covid-19 in the municipality of Rio de Janeiro, was widely shared on Facebook by the members of AfroBrazilian religions, along with messages of criticism and concern and recommendations that people continue to protect themselves.

In a video of May 29th 2020 published on her Facebook page and widely shared through social networks, Mãe Márcia Marçal 2021, iyálórị̀à of the Candomblé terreiro Ilê Axé Oluaiyè Ni Oyá, in Rio de Janeiro, responded to people who asked when she would celebrate the feast for her Pomba Gira, which was cancelled because of the pandemic. She stated that all Candomblé feasts and those for Exu in her terreiro are suspended until it is possible to leave home and meet safely. She stressed that "I don't think it's a propitious time for this, I don't think it's right to put my life, the lives of the members of my terreiro and my friends at risk by celebrating a Candomblé, a feast in the middle of this pandemic that hasn’t ended yet" (Mãe Márcia Marçal 2021 ${ }^{8}$ ).

She worships the òrișà in her terreiro by kneeling, praying and asking for physical and mental health for all. She stressed that:

What we have to do now is this: to ask for mercy, to ask for forgiveness, to ask for life, to ask for health, to ask for discernment, direction, to ask for a good head to help us. That's what we should ask for. I will use my strength, my faith to ask for all of us. That's what I want to do right now, that's what I've been doing for almost three months. And that's what I'm going to do in the meantime (Mãe Márcia Marçal 2021).

Mãe Márcia recommended that everyone take care of himself/herself, staying at home and avoiding bars, parties, meetings, crowds; and throwing parties for important occasions - as she did for her birthday in April—only with the people who live in one's home.

Stressing that the pandemic will pass and that it is important to preserve oneself until then, she recommended following her example: "I will wait for the train to pass to cross safely, to get out alive on the other side. This is the time to do this, to stay guarded and let it go.” (Mãe Márcia Marçal 2021).

Patience, one of the fundamental virtues in Afro-Brazilian religions, exercised in the daily life of terreiros and considered the main means of achieving long life, health and

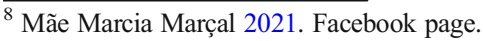


prosperity, is necessary in order to continue to respect social isolation. Azevedo and Peixoto (2014) stress, for example, that the custom in Candomblé terreiros of preparing food by hand, requiring more time than using appliances, constitutes an exercise of concentration, to train calm and patience.

In a myth reported in Sàlámì and Ribeiro (2011), Òrúnmilà, following the advice of Èșù, chose patience among the four àdo (gifts) that Olódùmarè offered him (prosperity, fertility, longevity and patience). In this way, he obtained all the other gifts, since these never stray far from patience.

Among the elements of nature used in therapeutic rituals and offerings to the òrișà in order to provide humans with their life force, patience is brought by the chicken, which has the strength to reproduce through its eggs and the patience to hatch them. But it is above all the igbin, the snail, which, as Bàbá Marcelo Monteiro, bàbálóriṣà of the Candomblé terreiro Àșe Idasile Odẹ, in Rio de Janeiro, points out, "has no feet or hands, but can get up to the tree; proceeds slowly, with patience ...; when the season is dry, it closes in its shell and comes out when the rain resumes" (Bàbá Marcelo, personal communication). Therefore, the igbin (Fig. 2) can provide human beings with the patience, calm and strength necessary to wait when the situation is difficult and to act at the right time, as highlighted in Calvo (2019).

Isolation, therefore, requires the ability to act as the igbin, with patience and remaining closed inside one's own house until Covid-19 passes, having preserved one's own life and health.

\section{The Challenge of Isolation}

Some Candomblé members commented on the first posts that recommended social isolation, stating that those who had experienced isolation and had lived the reclusion period in the ohunko ${ }^{9}$ were better able to face isolation during the pandemic.

When I asked how they were feeling in social isolation, some members of AfroBrazilian religions commented that, since they were "very domestic", they were able to live well in this situation, or that they have dedicated themselves to reading, meditation, crafts, gardening and cooking, managing thus to maintain a certain emotional and mental balance.

Lucio Sanfilippo of Logum Edé, egbon ${ }^{10}$ of the Candomblé terreiro Ilê Axé Iyá Nassô Oká - Ilê Oxum, in Rio de Janeiro, a singer, composer and physical education teacher, told me that he was living well in social isolation that continued in Brazil, since the "Numbers only grow...." He maintains daily contact with the members of his religious community and friends from the Casa de Logum Edé (his terreiro, that he began building before the pandemic) through Zoom and Google Meet, to chat and pray together. During the pandemic, he launched, on digital platforms, a new record with original music, that was nearing completion when the pandemic arrived in Brazil. In addition, he broadcasts lives once or twice a week and holds a weekly popular dance workshop with collaborative contribution from audience.

\footnotetext{
${ }^{9}$ Camarinha, room where the initiations are held.

${ }^{10}$ Lit. "Elder brother", person initiated in Candomblé for at least 7 years.
} 


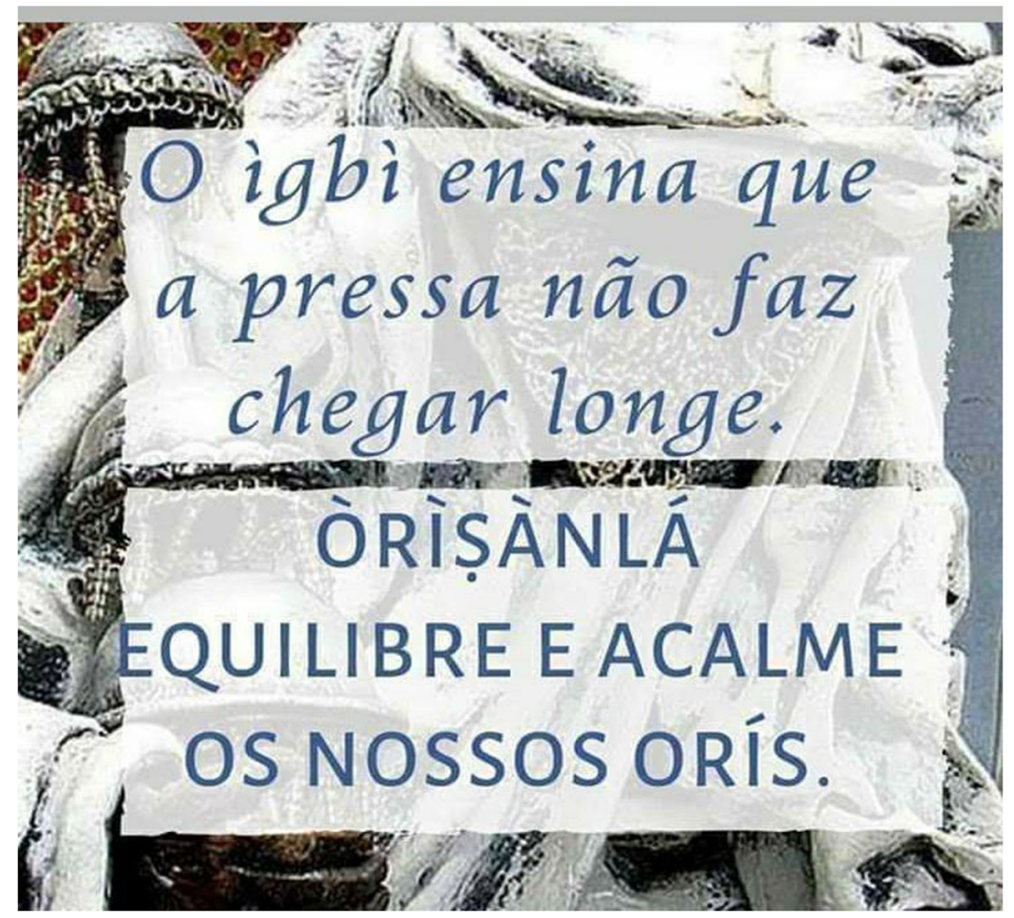

Fig. 2 Post that advises having the strength of the igbin. Source: Personal WhatsApp message received by the author from a member of Candomblé

Nininho Jhaazz, member of a Candomblé terreiro in Rio de Janeiro and singer, said that he was living completely isolated during this period; however, he maintains contact with the members of his religious community and his friends through social networks. He confessed to me that "the beginning of isolation was quiet, then came a time of great anxiety, which I treated with greater care with food, literature and praying to ask for better days" (Nininho Jhaazz, personal communication).

Other people have to leave their homes in order to work, so they adopt prevention and protection measures (wearing a mask, respecting safe distancing, washing hands and using hand sanitizer). However, for those who were accustomed to embracing the òrișà embodied during the feasts and the members of their religious community, where they feel welcomed and cared for, the isolation that continues today (and not knowing when it will end) is not easy. Some are like İyá Nenete of Òsun, who attends the Àse Idasile Odẹ: she continues to see her daughters and siblings who live near her house and maintains constant contact (through the phone and WhatsApp) with her religious community. In contrast, many people are far from their own families, unable to visit boyfriends or girlfriends, children, grandchildren or elderly parents who live far from them.

Doné Malu Paixão, of Ọya with Ọbalúaié, of the Àșe Idasile Odẹ, told me that in the beginning isolation was difficult, since "I was even sick from watching a lot of TV and just scared. I heard about a lot of friends who died, then I freaked out too. So, I decided to watch less television" (Doné Malu Paixão, personal communication). 
İyá Iva de Oșum, iyálórișà of the Candomblé terreiro Ilê Aṣè Fuminlayo Omin Dun, in Rio de Janeiro, told to me that she was facing isolation with great apprehension, dealing with something completely unknown. İyá Dári Obarainan, egbomin of the Candomblé terreiro Axé Viamão in Porto Alegre, told me that "I have respected social isolation as well as my family members. It's a difficult time for adaptation, because everything has stopped overnight, it's hard to adapt and create new routines" (İyá Dári Obarainan, personal communication). And Adriana of Yemojá, egbomin from Rio de Janeiro, told me that there are days when she feels very anxious because of negative thoughts, so she does meditation and breathing exercises and prays on her ori $i^{11}$ to calm down, and avoids watching the news and participating in discussions on social networks.

Many priests of Afro-Brazilian religions recognized the difficult and uncertain situation and the possible consequences of social isolation for psychological health, so they mobilized to mitigate them in different ways, including offering guidance and online care, psychological help, new modalities of being together in rituals and prayers - actions aimed at helping their religious community and the general population face the health crisis and its consequences ${ }^{12}$.

As Mameto Kamurici, ìálórișà of the Candomblé terreiro São Jorge Filho da Gomeia, in Lauro de Freitas, stated in an interview with the journal Correio of April 11th 2020: "For us, it is very difficult to be separated from each other. We're a religion of meetings, of feasts, we're a big family. But we are following the guidelines of the authorities ${ }^{13}$."

Many of my interviewees recognized the same lack of physical contact and expressions of affection with their friends. For example, Lucio Sanfilippo, although he is living well in isolation and offsetting the distance with an intensification of contacts through social networks, said that: "What is really lacking is affection, a hug, a kiss on the hand at the time of blessing, eating together, drumming, dancing, singing. But it's all going to pass" (Lucio Sanfilippo, personal communication).

In Mãe Márcia Marçal's video, she acknowledged that many people, especially those who live alone, may be suffering from depression, have their ori unbalanced and need help. She stated that many people were asking for her help, to talk to her and that:

I talk, I try to cheer up because, thanks to my father Obalúaié, ${ }^{14}$ my head is fine, so I can talk. And if my head is not good, I have my bàbálórișà and I will talk to him, I will call him, I will send a message, I will talk to him and he will help my head, or I call a friend to talk. And I do so with those who seek me: I talk, I try to cheer them up, and I ask for strength from Obalúaié, I ask for energy from Obalúaié. I ask the mother of the head, of the ori, ${ }^{15}$ to put my head in order. That

\footnotetext{
${ }^{11}$ Ori is usually translated as "head", but encompasses a complexity that includes material, spiritual and ancestral elements; it is the basis of personal destiny and an object of great care in Candomblé, as analyzed, for example, in Calvo (2019) and Dias (2013).

${ }^{12}$ These actions provide for the dissemination of news and guidelines to avoid contagion; offer spiritual support, economic aid and distribution of food and hygiene products to those in need, including production and distribution of masks; offer legal assistance and organize debates on various problems that continued or worsened during the pandemic, such as racism, religious intolerance and domestic violence.

${ }^{13}$ Correio 11 Apr 2020.

${ }^{14}$ Her órìșà.

${ }^{15}$ Yemọjá.
} 
is what people should do, to try to help those who are in need now (Mãe Márcia Marçal $2021^{16}$ ).

Some posts, widely shared through Facebook, express the difficulty of facing isolation and ask for comfort and help in case of need. I quote, for example, a post I found on different Facebook profiles of my friends of Afro-Brazilian religions:

Especially during all this isolation, things can get difficult mentally for some! Depression, anxiety and post-traumatic stress are very real. I would like twentytwo of my friends to post this (not share), so I know who I can talk to if I ever need someone. I think I know who's going to do this. I'm here שI dim.

Another problem that presents itself during isolation is the difficulty of coexistence with family members, which has even led to an increase in domestic violence and feminicides, ${ }^{17}$ a theme that gave rise to several debates organized by members of AfroBrazilian religions, some of which were especially dedicated to black women. İyá Dári Obarainan stressed that:

I believe this pandemic situation will be a lesson. I had lost my routines, I need to face domestic problems with my family, to which we did not pay attention, because we live in a very busy world. I faced my inner self, I had to deal with myself isolated, silent. The silence was good, I could hear myself. Anyway, I was able to calm the avalanche of unbridled thoughts (İyá Dári Obarainan, personal communication).

Bábà Mòlá pointed out the same problem, presenting the actions he is undertaking through social networks in order to raise awareness, dialogue, guide and motivate people:

In this period of isolation, several symptoms are active within the person and this, if it is in an accentuated, somatized way, ends up creating pathologies. So, as I really like the treatment of the human soul, I make a live event on Facebook every Wednesday at $7 \mathrm{pm}$. They are aimed at self-help, in order to calm the soul, the spirit, to say that it is normal for people to feel loneliness, loneliness in two, in three, because many family members are distant in this postmodern life. Life went so far as to distance even the family members and, when they were forced to live together, in the social moment of this pandemic, they began to meet themselves. Many caused problems, fights, then there was a very large increase in feminicides, family conflicts. So, I tried to focus on these lives for people to meet again, to join hands again. [...] To know that we can cry, suffer, feel pain, smile, celebrate, contemplate. This is all part of the human being, it's the balance. The balance is that you have everything organized and have everything that

\footnotetext{
${ }^{16}$ Mãe Marcia Marçal 2021. Facebook page.

${ }^{17}$ See, for instance, Agência Brasil 01 Jun 2020.
} 
makes up the human being. So, in all lives I always bring up these issues, of the complexity of the human soul, of this machine that moves us. [...] Lives are made on my Facebook profile and are also transmitted on the Facebook page of the Ille Òbá tì Șàngó 2021. ${ }^{18}$ It's every Wednesday. They are about lack, depression, the difference between depression, panic and sadness (which is often confused with a crisis of loneliness, but sadness is inherent to the human being) (Bàbá Mòlá, personal communication).

In this way, he adapts the role of the bàbálórișà — of listening, dialoguing and advising - to the situation of isolation and the new media, through his lives and selfhelp posts that he shares daily on his Facebook profile.

I note that meetings, lives, seminars and weekly debates also help many people deal with the new routine imposed by isolation and find a tone of normality, making days less similar to one another.

\section{Virtual Connections}

In everyday life, physical proximity and congregation of the religious community are replaced by a great intensification of virtual communications, in order for people to remain connected and feel the closeness and support of one another. They are united to be stronger, united to fight the common enemies: the new coronavirus, and the structural racism that increases the vulnerability of Blacks to the pandemic. ${ }^{19}$

I myself received affection and care messages before seeing them and returning them to my friends from Afro-Brazilian religions. In fact, in January I returned to Italy and when, at the end of February, the Italian government began to cancel events and close some cities because of the spread of Covid-19, I received many messages from my friends in Brazil, including many people from Afro-Brazilian religions. They asked me how I and my family were, what the situation was like in my city, recommended that we take care of ourselves and not leave the house and sent blessings from the orìsà to protect us and preserve us in health. Subsequently, when Covid-19 arrived in Brazil, messages of concern and requests for information began to go in both directions and flood WhatsApp groups that bring together people from the same terreiro. The persons who contracted Covid-19 had the constant support of their friends, with desires for prompt recovery, requests for information about their state of health and how they were taking care of themselves, ${ }^{20}$ recommendations and advice, messages of affection and blessings of the òriṣà.

In social media (mainly WhatsApp and Facebook), people of Afro-Brazilian religions who contracted Covid-19 asked others to pray for them and communicated updates on their health status, receiving many comments of support and blessing.

\footnotetext{
18 Ìlé Òbá Tí Sàngó. Facebook page.

${ }^{19}$ As different articles show and as Baba Diba de Iyemonja denounced in a video published on the Facebook page of RENAFRO Saúde, Blacks are more exposed to the risk of contagion and death from Covid-19. See, for instance, Estadão 04 May 2020 and Jornalistas Livres 20 Mar 2020.

${ }^{20}$ All the people of Afro-Brazilian religions that contracted Covid-19 I was in contact with followed the directions of their physician or went to the hospital. Few of them accompanied these cares with some herbal tea in order to soothe the symptoms and anxiety.
} 
Deaths from Covid- $19^{21}$ were also communicated through these means, with the intention of informing about the passing of the person, and also to reinforce the discourse of the importance of adopting prevention measures and not underestimating the pandemic.

Although they live in the same city, the members of Afro-Brazilian communities do not go out together and do not gather in their terreiro and they communicate mainly through phone and digital media.

For İyá Dári Obarainan, social networks, which she previously used primarily to do research on subjects of interest, have become a very useful means of communication. She told me that she keeps in touch with her family members, to be informed about their health situation, whether they had contact with someone who contracted Covid19 , if they present any symptoms and if they continue to respect the protective measures. She said: "I had the opportunity to make better use of social networks... not only to research, but also to get close to loved ones at this difficult time... I did not stop seeing them: somehow, we were together even in a liquid world, in the sense of Bauman" (İyá Dári Obarainan, personal communication).

For İyá Glicia de Iyansã, social networks and webinar applications became the means of communication during the pandemic:

Contact with the broader family of àșe is made through social networks and webinar applications. We chose to use Zoom because everyone can be present at the same time. We have a day and a scheduled time when we meet to make rules, to dialogue, to make ourselves understood. Any other particular need is addressed by the social network in private (İyá Glicia de Yansã, personal communication).

Bábà Mòlá stressed the ease of communication provided by social networks, compared to using correspondence or the phone, and the possibility of reaching a large number of people to help and comfort them. He stated that "Every morning I post messages of self-help and thus I communicate with the public, with a spiritual, logical nature, but something motivational, something that effectively lifts the depths of each one" (Bàbá Mòlá, personal communication). And, in fact, by visiting his Facebook profile and the İlé Òbá tì Sàngó page, I found daily posts like "I see many people wondering why they aren't working, and the answers are always in them good morning / \#babamola", "Life is like a book, to find out more, one has to open it, do not just stay on the front cover good day / \#babamola" and "The question that cannot be silenced within each of us, 'how does this contribute in my life?' good morning / \#babamola".

In many Facebook profiles of people of Afro-Brazilian religions, photos of prepared foods, pets, artisanal work, the view from their window, past meetings and feasts continue to be shared, in order to make one's own daily life closer to friends and to maintain connections at a distance.

\footnotetext{
${ }^{21}$ The ritual of așéșé, usually celebrated in case of death of a candomblé member, was reduced in form and time and restricted to a smaller group of persons in order to avoid gatherings. Some problems arose from the impossibility to perform some acts of this ritual, because of sanitary protocols for dead people, especially in case of death for Covid-19, as pointed out in Blog IDAFRO (2020) 02 May 2020 and Correio 03 April 2020.
} 
The importance of being united is expressed in the African concept of Ubuntu, the interdependence among people and the value of unity. This represents a fundamental value of Afro-Brazilian culture and is the concept behind different initiatives taking place during the pandemic, including different actions of members of Afro-Brazilian religions to protect themselves from Covid-19, as analyzed in Calvo (2020). Ubuntu was widely valued in the social networks and by my interviewees, together with the need to rethink society following the pandemic. For example, İyá Nenete of Òsun stated that "This isolation made me see with much more clarity that we need to unite more. [...] I hope with great faith that this pandemic will end soon and that we will be more humble and fraternal" (İyá Nenete, personal communication).

Some posts contributed to reaffirming people's sense of religious belonging and identity as members of their terreiro, forming a social media challenge whose circulation continues to increase. One of these posts announces:

To the people of Candomblé. If I've tagged you, don't let me down. If I didn't tag you, please, no offense. I have tried to choose people who proudly carry their ancestry, people who are great examples within Afro-Brazilian traditions, in times of worldwide complacency, we will make this challenge a tribute to our elders, our youngers and our peers, and to our orixás!!

With so much negativity out there, let's do something positive and show the world how united we are.

Post a photo, dressed in a ritual outfit, just you!!!! Then tag as many members of Afro-Brazilian religions as you want, men and women of faith, warriors and enlightened to do the same copy and paste... Let's fill Facebook with axé and love to others

[Photo of the person in ritual clothing]

Challenge done

I was tagged by [the person's name].

I thank you all for the affection and remembrance. Mòjúbà!!! ${ }^{22}$

In other posts, always accompanied by an invitation to be imitated, people write a small autobiography with their trajectory and their most remarkable experiences as a member of an Afro-Brazilian religion, accompanying it with their own photo in ritual clothes or during a celebration in their terreiro.

Social networks have also served to criticize and condemn conduct considered inappropriate in the pandemic situation, amplifying the function of regulating social relations and affirming ethical values that gossip plays within the terreiros. For example, a video that circulated on Facebook and WhatsApp, showing a feast for the òrișà during the pandemic, where everyone wore masks and kept a certain distance from each other, received much criticism, since they did not follow the calls to suspend public celebrations. A friend of Candomblé sent me a post, which circulated on Facebook, criticizing a priest who held an initiation during the pandemic: "The babalorixá who put 4 iyawos $^{23}$ in Mauá is dead from covid 19 and the 4 iyawos are

\footnotetext{
${ }^{22}$ Mojuba is a traditional courtesy form.

${ }^{23}$ Initiated four persons.
} 
infected. 2 are in serious condition I just heard from a friend. Very sad.” In a Facebook group where members of Candomblé participate to discussions on different themes, the post of a bàbálórìsà complaining that many people were criticizing his decision to celebrate a feast for the òrișà in his terreiro, stating that he believes in the protection of the òrișà and that he didn't oblige anyone to come, many comments affirmed the importance to respect social isolation, avoid gatherings, take care of one's health and be responsible with the others.

\section{Prayers and Rituals During the Pandemic}

During isolation, teachings, debates, seminars, prayers and invocations were shared through social networks. For example, Lucio Sanfilippo told me that he is in daily contact with members of his terreiro: "We pray daily to Omolú, the Lord of Healing, and Òsányìn, the Lord of leaves, the one who enchants the leaves to turn them into medicine. We also pray for the orìsà of the day. Today, we are praying, in addition to Ọbalúaié and Òsányìn, for Oșálá, since it is Friday" (Lucio Sanfilippo, personal communication). Every Monday, at 7:00 pm, several terreiros in the country meet virtually to make invocations for a cure for Covid-19.

The rituals, performed by priests alone or with the strict group of people who live in the terreiro, bring together the intentions and requests of the members of the religious community (sometimes extending their reach to other terreiros and the general public) and are shared through photos, videos and lives (Fig. 3).

In addition to the rituals of the liturgical calendar, prayers and offerings are made to certain òrișà, whose powers are invoked, asking for protection from Covid-19 and a quick exit from the pandemic. First and foremost is Obalúaié/ Omulu/Sakpata/Nsumbu, which is, at the same time, the òrișà of smallpox and contagious diseases, and healing (Fig. 4).

In the terreiro of İyá Glicia of Yansã, collective rituals are suspended, but offerings, prayers and invocations are still performed by the people who reside in the terreiro. She pointed out that:

The terreiros have a duty to care for others, the duty to care not only for themselves, for the òrìsà, but also for the physical integrity of others. Therefore, collective rituals are suspended, but, as the òrìnà need to continue to be taken care of, we are continuing to care for the òrișà with the people who reside in the Àse, who are also in social isolation (İyá Glicia of Yansã, personal communication).

Bábà Mòlá also held rituals in his terreiro, sharing photos and videos with the members of the religious community:

I did rituals for Omolú asking for peace in the world, a cure, a way for us to find the path that brings us a little more security. I also did a live with the ritualistic nature of prayer to share with people, to share my prayers here. I did it in isolation, some did by the WhatsApp group of the terreiro, we got together and 


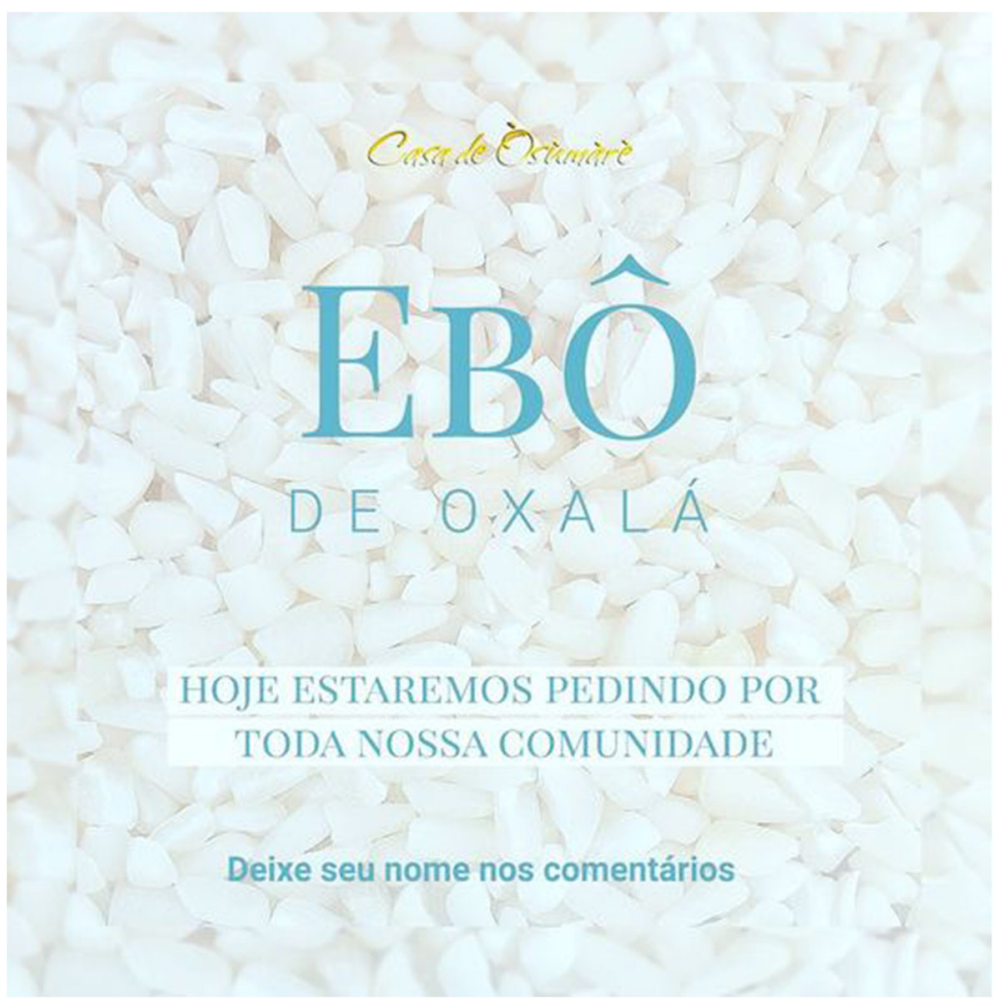

Fig. 3 Post from the Casa de Oxumare in Salvador calling people to write their name in order to receive prayers during the offerings to Oșálá. Source: Casa de Oxumarê Facebook page

we got into a current, even if virtual, for health, for peace. And I also did it for Sọngọ, because Șọngọ represents life, besides being the patron of the terreiro (Bàbá Mòlá, personal communication).

The use of social networks also allowed the sharing of rituals and prayers with a very large number of people, from one side of the country to the other. For example, Doné Malu Paixão sent me pictures of the àmàlà ${ }^{24}$ and the bonfire for Sọngọ and the acarajé for Oya, that she prepared in her house. On those occasions, she also made an offering and prayers to the orị̀à at the request of a friend, to help her in a difficult situation she was facing. And from Rio de Janeiro, she saw through Facebook ${ }^{25}$ that the Casa de Òsùmàrè of Salvador made a bonfire for Sọngọ that continued burning for 12 days.

Bàbá Marcelo of the Àse Idasile Odẹ, on the occasion of the ritual for Ògún, celebrated in June, made, in place of the àgbo (bath) that is usually distributed among the participants of the ritual, oșe dúdú (bar of black soap), since it can be preserved for a longer time and the members of the religious community could get it when they could go there safely, in order to absorb the àșe $e^{26}$ that was concentrated there.

\footnotetext{
${ }^{24}$ Main offering for Șọngọ.

${ }^{25}$ Casa de Oxumarê. Facebook page.

${ }^{26}$ Force.
} 


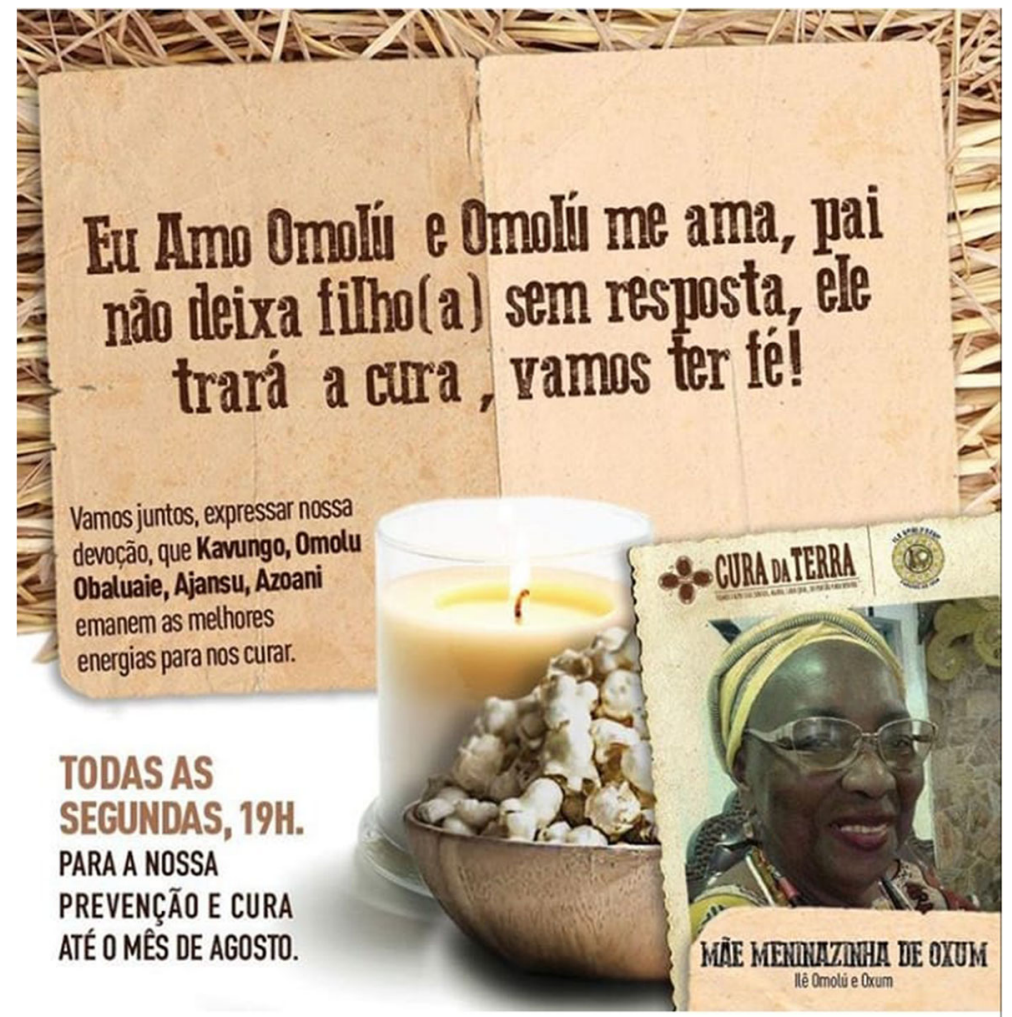

Fig. 4 Post announcing collective prayers to Obalúaié online. Source: Ilê Omolú e Oxum Facebook page

Some priests hold online consultations; others receive people only in severe cases (following a strict hygiene protocol, social distancing and using masks) and carry out the $e b o^{27}$ with a minimum number of people, as does İyá Cristiane of Logun'Edé, íyálórișà of the Candomblé terreiro Ilê Ase Logun'Edé in São Gonçalo (RJ). Others do not receive anyone, like İyá Dári Obarainan, who explains to people who ask for a consultation or to make an offering to Eșù that she does not let anyone enter her house, in order to protect her family from Covid-19, but she accepts their prayers and their offerings and delivers them to Èșù in their name.

Bàbá Marcelo Monteiro, in a message that he published in the WhatsApp groups of the Àse Idasile Ode, of the Egbé Ifafunké, ${ }^{28}$ of $\mathrm{CETRAB}^{29}$ and his social media-in order to report the result of the oracular consultation about Covid-19 made by the traditional worshippers Àșà Orị̀sà in Oyo, Nigeria - underscored the necessity of following the protocols in order to prevent contagion, but: "We can't deny taking care of our own. We need to do things so that the Earth doesn't take us. Maintaining isolation and avoiding crowds does not mean that our homes are closed to welcome the

\footnotetext{
${ }^{27}$ Offerings.

28 The Ifá Society founded by Bàbá Marcelo.

${ }^{29}$ Center of Afro-Brazilian Traditions, an NGO founded by Bàbá Marcelo.
} 
sick and people in need. Taking care of our members is critical right now' (Bàbá Marcelo Monteiro).

Lucio Sanfilippo told me that he made offerings and baths for the people who needed it and for himself:

I prepared Omolokun $^{30}$ in my house for some pregnant daughters, sisters, goddaughters, we prayed together, each one in his or her own house. I prepared food for Ốsóósì and Logum Edé, since my $O d u n^{31}$ was just when the isolation began, at the end of March. A satisfaction for Obará, ${ }^{32}$ too. Wednesday, I had to go out to bring food to the homeless brothers which is the mission given to me by Tranca Rua das Almas. I took advantage and bought herbs for the bath. I let it soak to kill the virus, asked Òsányìn permission and threw it in the sink. Then I washed it very well, muddled, sang the leaves. I disinfected bottles and filled them with the bath for some people who really needed it (Lucio Sanfilippo, personal communication).

Those who have their òrișà in their house continue to worship them, like İyá Nenete and Adriana of Yemojá, although the pandemic imposes limitations:

As I already have an age of òrișà and know how to consult the oracle, I do it to know the dry food [with no animal sacrifice] the òrìsà likes to receive. I don't consult the oracle to see the ẹbo, because I think we're still in a very difficult time due to Covid, so I'm not going to some places to buy things (Adriana de Yemọjá, personal communication).

\section{Conclusions}

By voluntarily and almost unanimously adhering to social isolation in order to protect themselves and the members of their families and communities from SARS-Cov-2 contagion, the members of Afro-Brazilian religions have faced a new situation that often causes sadness, difficulties and sometimes psychological problems and family conflicts.

Strengthening contacts through social networks and the phone, they found new ways to communicate, to manifest affection and to help each other, but without physical contact and with the mediation of technology.

Rituals, prayers and invocations, which, before the pandemic, were also occasions for the religious community to gather, talk and eat together, and were often followed by drums, dances and the presence of the embodied òriṣà, gave way

\footnotetext{
${ }^{30}$ Food for Òșun, òrișà who takes care of pregnant women and of children in their first years of life.

${ }^{31}$ Commemoration of the initiation.

32 Essù lord of the body.
} 
to new ways of gathering all the members of the terreiro and bringing their requests to the òriṣà and spirits.

Social networks allowed for greater reach and participation, and connections among different terreiros. Thus, everyone is protecting him- or herself and his or her family while waiting for the health emergency to end when they can reunite and embrace again.

Acknowledgements I would like to thank all the devotees of Afro-Brazilian religions for sharing their experiences, thoughts and stories with me.

\section{Declarations}

Informed Consent Informed consent was obtained from all individual participants for whom identifying information is included in this article.

Conflict of Interest The author declares no competing interests.

\section{References}

Afrobras - Federação das Religiões Afro-Brasileiras (2020) Facebook page. https://www.facebook.com/ Afrobras-Federa\%C3\%A7\%C3\%A3o-das-Religi\%C3\%B5es-Afro-Brasileiras-390649827621964/ Accessed 22 Nov 2020.

Associação pede proibição de cremação de seguidores do Candomblé 2020. Correio. https://www. correio24horas.com.br/noticia/nid/associacao-pede-proibicao-de-cremacao-de-seguidores-docandomble/?utm_source=correio24h_share_facebook\&fbclid=IwAR0PB9V_s6zI0gtJD2GrYQkAmp_ KVzyl_KOxMjP2bghhadYkj2kddts9zTc Accessed 08 Apr 2021.

Azevedo MS (Mãe), Peixoto Domini G (2014) O que as folhas cantam (para quem canta folha). Brasília, Instituto Nacional de Ciência e Tecnologia de Inclusão no Ensino (INCTI).

Bandeira O, Carranza B (2020) Reactions to the pandemic in Latin America and Brazil: Are religions essential services? International Journal of Latin American Religions 4:170-193

Calvo D (2019) Cuidar da saúde com a força vital da natureza: tratamentos terapêuticos no Candomblé. Ph.D. in Social Sciences, Universidade do Estado de Rio de Janeiro, Rio de Janeiro.

Calvo D (2020) They agreed to kill us, we agreed not to die": Acts of love and resistance to confront Covid-19 by Afro-Brazilian religions members. In: Collecting COVID-19. A crowd-sourced digital ethnography of the COVID-19 Pandemic. Available via UCL Centre for Digital Anthropology. https://anthrocovid.com/ 2020/06/05/they-agreed-to-kill-us-we-agreed-not-to-die-acts-of-love-and-resistance-to-confront-covid19-by-members-of-afro-brazilian-religions/. Accessed 21 Jan 2021

Casa de Oxumarê. Facebook page. https://www.facebook.com/casadeoxumare/ Accessed 08 Jan 2021.

Casos de feminicídio crescem 22\% em 12 estados durante pandemia (2020). Agência Brasil. 01 Jun 2020. https://agenciabrasil.ebc.com.br/direitos-humanos/noticia/2020-06/casos-de-feminicidio-crescem-22-em12-estados-durante-pandemia Accessed 29 Nov 2020.

Costa Lima V da (1977) A Família de Santo nos Candomblés Jeje-Nagôs da Bahia: um estudo de relações intragrupais. Salvador, Corrupio.

Daniel Höfling: A Casa-Grande propaga o coronavírus Covid-19. (2020) Jornalistas Livres. https:// jornalistaslivres.org/daniel-hofling-a-casa-grande-propaga-o-coronavirus-covid-19/ Accessed 24 Nov 2020.

Dias Ferreira J (2013) Orí O! A ideia de Pessoa, a Problemática do Destino e o Ritual do Bọí entre os Yorùbás e um Olhar ao Candomblé. In: Horizonte 11 (29): 70-87.

Em isolamento, devotos do Candomblé evocam orixá da cura. (2020) Correio. https://www.correio24horas. com.br/noticia/nid/em-isolamento-devotos-do-candomble-evocam-orixa-da-cura/?utm_source=

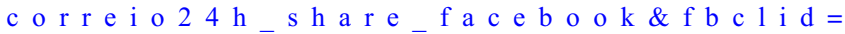


IwAR1BALjLAQUgw9OOPDRWYDXHLbyKxWYIZ1rSk3EyRQFNWE5XLdat_bGvLo8 Accessed 25 Nov 2020.

Em SP, risco de morte de negros por Covid-19 é $62 \%$ maior em relação aos brancos. (2020) Estadão. https:// saude.estadao.com.br/noticias/geral,em-sp-risco-de-morte-de-negros-por-covid-19-e-62-maior-emrelacao-aos-brancos,70003291431 Accessed 24 Nov 2020.

Idafro - Instituto de Defesa dos Direitos das Religiões Afro-Brasileiras. (2020) Blog. Funerais religiosos em tempo de coronavírus. https://www.idafro.org.br/index.php/blog/38-funerais-religiosos-em-tempos-decoronavirus Accessed 08 Apr 2021.

Ìlé Òbá Tí Sàngó. (2021) Facebook page. https://www.facebook.com/ileoba197 Accessed 08 Jan 2021.

Ilê Omolu e Oxum. (2021) Facebook page. https://www.facebook.com/IL\%C3\%8A-OMOL\%C3\%9A-EOXUM-163760910410553 Accessed 08 Jan 2021.

Isolamento cai e município do Rio volta a ter aumento de notificações do novo coronavírus. (2020) Extra. https:/extra.globo.com/noticias/rio/isolamento-cai-municipio-do-rio-volta-ter-aumento-de-notificacoesd o - n o v o - c o r o n a vi r u s - 24491785 . h t m l ? f b c 1 i d = IwAR2NXxUV6kLCvTh7JRZNrT4GPiXyfTE3mPZ1p0Tu2WWXcWUjDMfSEDFxCcw Accessed 25 Nov 2020.

Mãe Marcia Marçal. (2021) Facebook page. https://m.facebook.com/M\%C3\%A3e-Marcia-Mar\%C3\%A7al1724467474436556/ Accessed 08 Jan 2021.

Souza Pinto, Olavo Filho. (2020) A Família Nagô. Composições entre o sangue e o santo no candomblé do Recife. Ph.D. in Social Anthropology, Universidade de São Paulo, São Paulo.

Rabelo M (2014) Enredos, Feituras e Modos de Cuidado. Dimensões da Vida e da Convivência no Candomblé. Salvador, EDUFBA.

Sálàmì S (King) Ribeiro R Iyakemi (2011) Exu e a ordem do universo. São Paulo, Editora Oduduwa.

Renafro Saúde. (2020) Facebook page. https://www.facebook.com/renafrosaudeoficial/photos/a. 1024573947694780/1572432176242285/?type=3\&theater Accessed 25 Nov 2020.

Publisher's Note Springer Nature remains neutral with regard to jurisdictional claims in published maps and institutional affiliations. 